\title{
Analisis Pengaruh Faktor Pribadi dan Budaya Terhadap Keputusan Pembelian
}

\author{
Nina Herlina*, Yuyun Susanti, Asep Edwin Ramadhan. \\ Universitas Galuh Ciamis \\ JL. R.E. Martadinata, No. 150 Ciamis, Jawa Barat, Indonesia \\ * $\underline{\text { nitatamasampurna@gmail.com }}$
}

\begin{abstract}
This study aims to determine: 1) The magnitude of the influence of personal factors on purchasing decisions at Alfamart Batukaras; 2) The magnitude of the influence of cultural factors on purchasing decisions at Alfamart Batukaras; 3) The magnitude of the influence of personal and cultural factors on purchasing decisions at Alfamart Batukaras. The research method used in this study is an explanatory survey research method with a quantitative data approach. The number of population that will be used as the object of research is the number of consumers of Alfamart Batukaras in December 2019 as many as 1,698 people. The sample size selected was 94 people. Data collection techniques in this research are library research, field studies (observations, interviews and questionnaires). Based on the results of the study that: 1) There is a positive and significant influence on personal factors on consumer purchasing decisions at Alfamart Batukaras. This means that if personal factors increase then consumer purchasing decisions will increase; 2) There is a positive and significant influence of cultural factors on consumer purchasing decisions at Alfamart Batukaras. This means that if cultural factors increase, consumer purchasing decisions will increase, 3) There is a positive and significant influence of personal and cultural factors on consumer purchasing decisions at Alfamart Batukaras. This means that if personal factors and cultural factors increase then consumer purchasing decisions will increase.
\end{abstract}

Keywords : Personal Factors; Cultural Factors; Purchase.

Abstrak - Penelitian ini bertujuan untuk mengetahui: 1) Besarnya pengaruh faktor pribadi terhadap keputusan pembelian pada Alfamart Batukaras; 2) Besarnya pengaruh faktor budaya terhadap keputusan pembelian pada Alfamart Batukaras; 3) Besarnya pengaruh faktor pribadi dan faktor budaya terhadap keputusan pembelian pada Alfamart Batukaras. Metode penelitian yang digunakan dalam penelitian ini adalah metode penelitian survey explanatory dengan pendekatan data kuantitatif. Jumlah populasi yang akan dijadikan objek penelitian adalah jumlah konsumen Alfamart Batukaras pada bulan Desember 2019 yaitu sebanyak 1.698 orang. Ukuran sampel yang dipilih adalah sebanyak 94 orang. Teknik pengumpulan data dalam penelitian ini adalah studi kepustakaan, studi lapangan (observasi, wawancara dan angket). Berdasarkan hasil penelitian bahwa : 1) Terdapat pengaruh yang positif dan signifikan faktor pribadi terhadap keputusan pembelian konsumen pada Alfamart Batukaras. Artinya jika faktor pribadi meningkat maka keputusan pembelian konsumen akan meningkat; 2) Terdapat pengaruh yang positif dan signifikan faktor budaya terhadap keputusan pembelian konsumen pada Alfamart Batukaras. Artinya jika faktor budaya meningkat maka keputusan pembelian konsumen akan meningkat, 3) Terdapat pengaruh yang positif dan signifikan faktor pribadi dan faktor budaya terhadap keputusan pembelian konsumen pada Alfamart Batukaras. Artinya jika faktor pribadi dan faktor budaya meningkat maka keputusan pembelian konsumen akan meningkat.

Kata Kunci : Faktor Pribadi; Faktor Budaya; Pembelian.

\section{PENDAHULUAN}

Keputusan pembelian merupakan suatu konsep dalam perilaku pembelian dimana konsumen memutuskan untuk bertindak atau melakukan sesuatu dan dalam hal ini melakukan pembelian ataupun memanfaatkan produk atau jasa tertentu [1]. Bisnis Ritel di Indonesia makin hari dirasakan semakin ramai dan persaingan bisnisnya menunjukan perkembangan yang cukup pesat, namun tidak menjadi halangan bagi para pengusaha ritel untuk menambah jumlah outletnya diberbagai wilayah, apalagi setelah meningkatnya sejumlah minimarket baru dari berbagai perusahaan ritel yang menyelenggarakan programprogram tertentu. Keberadaan perusahaan ritel yang bermunculan di dalam negeri dari perusahaan ritel yang berkembang ini dalam negeri khususnya minimarket seperti Indomart, Alfamart, Ceriamart, Yomart dalam rangka menghadapi arus persaingan yang semakin ketat para perusahaan ritel harus sesegera mungkin mengatur strategi marketing dengan sedemikian rupa agar perusahaan tetap bertahan di persaingan pasar ritel yang semakit ketat.

Pada saat ini pemasaran barang atau jasa umumnya tidak dapat dikerjakan langsung dari produsen ke konsumen, melainkan harus melalui beberapa perantara yang menyalurkan barang dari produsen ke konsumen yang dikenali dengan sebutan lembaga saluran distribusi (saluran pemasaran) ritel merupakan kegiatan yang sangat penting dalam menyampaikan barang dari produsen ke konsumen. Hal tersebut tidak lepas dari tuntutan kebutuhan masyarakat yang ingin serba praktis. 
Pada sistem manajemen modern fungsi perencanaan dan pengendalian merupakan hal yang penting sebagai inti dari fungsi manajemen. Fungsi perencanaan berhubungan dengan proses berpikir dalam mengambil keputusan atau langkah-langkah tentang cara bertindak setelah mempertimbangkan anternatif beberapa kemungkinan yang terjadi. Sedangkan fungsi pengendalian merupakan proses untuk menjamin bahwa perusahaan telah melaksanakan rencana secara efektif dan efisien. Begitu pula dalam proses pemasaran [2].

Keputusan pembelian menjadi suatu hal yang penting untuk diperhatikan karena hal ini tentu akan menjadi suatu pertimbangan bagaimana suatu strategi pemasaran yang akan dilakukan oleh perusahaan berikutnya. Keberhasilan perusahaan dalam mempengaruhi konsumen dalam keputusan pembelian sangat didukung melalui upaya membangun citra merek kepada konsumen dengan membangun kualitas dari produk itu sendiri kepada konsumen dengan strategi pemasaran, serta melakukan inovasi untuk varians-varians baru pada suatu produk. Proses pengambilan keputusan pembelian yang rumit seringkali melibatkan beberapa keputusan. Suatu keputusan melibatkan pilihan diantara dua atau lebih alternatif tindakan.

Keputusan pembelian adalah suatu reaksi seseorang terhadap beberapa solusi alternatif yang dilakukan secara sadar dengan cara menganalisa kemungkinan-kemungkinan dari alternatif tersebut bersama konsekuensinya. Alfamart merupakan milik PT. Sumber Alfaria Trijaya, Tbk yang merupakan perusahaan waralaba swalayan yang menjual barang keperluan sehari-hari. Alfamart adalah salah satu saluran distribusi yang bertujuan untuk memenuhi permintaan konsumen dalam pemenuhan kebutuhannya. Sebagai salah satu usaha yang bergerak dalam usaha ritel Alfamart tentunya harus memperhatikan strategi pemasaran yang ditetapkan dalam mempengaruhi konsumen untuk melakukan keputusan pembelian. Seiring dengan dikeluarkannya PERDA Kab. Ciamis No. 18 Tahun 2008 tentang penyelenggaraan pasar, geliat usaha yang bergerak dalam bidang pemasaran semakin meningkat.

Namun demikian, berdasarkan hasil observasi dan wawancara awal yang penulis lakukan dengan kordinator area pada Alfamart Batukaras diketahui bahwa keputusan pembelian konsumen belum sepenuhnya optimal, hal tersebut dapat dilihat dari terjadinya penurunan konsumen tersebut diakibatkan oleh belum optimalnya tingkat keputusan konsumen untuk membeli produk yang dipasarkan oleh Alfamart
Batukaras, selain itu masih ada konsumen yang beranggapan bahwa harga produk yang dipasarkan oleh Alfamart masih cukup mahal dibandingkan dengan toko kelontongan lain, mengingat banyak perusahaan-perusahaan ritel dan toko sejenis yang ada di daerah Cijulang khususnya di daerah Batukaras. Selain itu, produk yang ada di Alfamart Batukaras masih kurang lengkap dibandingkan dengan produk yang ada di minimarket yang lain sehingga berdampak pada keputusan pembelian konsumen.

Hal tersebut diperkuat oleh data mengenai jumlah konsumen yang membeli produk di Alfamart Batukaras selama bulan Agustus-Desember 2019 sebagai berikut:

Tabel 1. Data Penjualan Alfamart Batukaras Periode Bulan Agustus - November 2019

\begin{tabular}{clcc}
\hline No & Bulan & $\begin{array}{c}\text { Jumlah Konsumen yang } \\
\text { Membeli Produk }\end{array}$ & $\begin{array}{c}\text { Persentase } \\
(\boldsymbol{\%})\end{array}$ \\
\hline 1 & Agustus & 1.439 & - \\
2 & September & 1.721 & 19,60 \\
3 & Oktober & 1.635 & $-5,00$ \\
4 & November & 1.899 & 16,15 \\
5 & Desember & 1.698 & $-10,58$ \\
\hline \multicolumn{2}{l}{ Sumber: [3] }
\end{tabular}

Berdasarkan tabel 1 tersebut maka dapat diketahui bahwa jumlah konsumen yang membeli produk pada Alfamart Batukaras berfluktuasi. Hal tersebut dapat dilihat dari jumlah konsumen yang membeli produk pada bulan Agustur 2019 yaitu sebanyak 1.439 orang, sementara pada bulan September meningkat menjadi sebanyak 1.721 orang atau mengalami kenaikan sebesar 19,60\%. Pada bulan Oktober jumlah konsumen yang membeli produk menjadi sebanyak 1.635 orang atau mengalami penurunan sebesar 5\% dari bulan September, dan pada bulan November 2019 jumlah konsumen yang membeli produk yaitu sebanyak 1.899 orang atau mengalami peningkatan sebesar 16,15\% dari bulan Oktober. Sedangkan jumlah pembeli pada bulan Desember yaitu sebanyak 1.698 atau mengalami penurunan sebesar 10,58\% dari bulan November [3]

Salah satu faktor yang dapat mempengaruhi tingkat keputusan pembelian konsumen adalah faktor pribadi, keputusan seorang konsumen dipengaruhi oleh pribadinya, dalam hal ini yaitu mengenai usia dan tahap siklus hidup, pekerjaan, keadaan ekonomi, gaya hidup, kepribadian dan konsep diri. Pribadi sering diartikan sebagai karakteristik individual yang merupakan perpaduan dari riset, tempramen, 
kemampuan umum dan bakat yang dalam perkembangannya dipengaruhi oleh interaksi individu dengan lingkungannya. Pribadi juga diartikan sebagai karakteristik yang ada di dalam diri individu yang melibatkan berbagai proses psikologis yang akan menentukan kecenderungan dan respon seseorang terhadap lingkungan. Karakteristik pribadi konsumen dapat dilihat dari kemampuan ekonominya, gaya hidup, kepribadian, serta karakter-karakter pribadi lain yang dimilikinya. Perilaku pembelian konsumen dipengaruhi oleh factor budaya, faktor sosial, faktor pribadi, dan faktor psikologis.

Keputusan pembelian konsumen dipengaruhi oleh karakteristik pribadi. Karakteristik tersebut meliputi; usia dan tahap siklus hidup, pekerjaan, keadaan ekonomi, gaya hidup, serta kepribadian dan konsep diri pembeli [4]. Faktor pribadi adalah merupakan suatu cara mengumpulkan dan mengelompokkan kekonsistenan reaksi seorang individu terhadap situasi yang sedang terjadi.

Keputusan pembeli sangat dipengaruhi oleh karakteristik pribadi konsumen, faktor pribadi tersebut meliputi usia dan tahap dalam siklus hidup pembeli, pekerjaan dan keadaan ekonomi, kepribadian dan konsep diri, serta gaya hidup dan nilai. Namun demikian, berdasarkan hasil observasi dan wawancara awal yang penulis lakukan dengan kordinator area pada Alfamart Batukaras diketahui bahwa faktor pribadi konsumen belum sepenuhnya optimal, hal tersebut dapat dilihat dari tingkah laku konsumen dalam memilih tempat belanja khususnya perusahaan ritel dan melakukan keputusan untuk pembelian. Selain itu permasalahan yang sering ada dalam pembicaraan para pembeli itu adalah mengenai varians serta kelengkapanproduk yang dipasarkan oleh Alfamart. Serta daya beli masyarakat masih rendah disebabkan karena kurangnya kepercayaan terhadap produk yang dipasarkan baik dari segi harga maupun keragaman produk.

Selain faktor pribadi, faktor budaya juga merupakan faktor yang dapat mempengaruhi keputusan pembelian konsumen. Faktor budaya merupakan penentu keinginan dan perilaku yang paling mendasar untuk mendapatkan nilai, persepsi, preferensi dan perilaku dari lembaga-lembaga penting lainnya". Faktor kebudayaan mempunyai pengaruh yang paling luas dan paling dalam terhadap perilaku konsumen. Pemasar harus memahami peran yang dimainkan oleh kultur, subkulkur dan kelas sosial pembeli.

Faktor budaya (culture) merupakandasar keingan dan perilaku seseorang yang akan berdampak pada keputusan pembelian konsumen, pemasar harus benarbenar memperhatikan nilai-nilai budaya jadi setiap negara untuk memahami cara memasarkan kualitas produk, berbagai macam menu makanan yang ditawarkan. Faktor budaya yang dimiliki oleh seseorang dapat mempengaruhi perilaku dalam kehidupan sehari-hari. Perilaku konsumen merupakan salah satu bagian dari budaya, oleh karena itu perilaku konsumen dapat dijadikan oleh para produsen atau pelaku bisnis sebagai acuan dalam menentukan strategi yang akan digunakan untuk memasuki suatu pasar. Perilaku konsumen menggambarkan bagaimana konsumen membuat keputusan-keputusan pembelian dan bagaimana mereka menggunakan dan mengatur pembelian barang atau jasa. Setiap orang pasti memiliki perilaku yang berbeda-beda dan pola pikir yang berbeda dalam memahami suatu hal. Termasuk dalam hal menanggapi rangsangan yang diberikan produsen kepada konsumen, misalnya dalam hal promosi atau penjualan suatu produk. Dengan adanya pola pikir yang berbeda-beda dari para konsumen, maka produsen perlu mengelompokkan perilakuperilaku konsumen yang sejenis agar strategi yang akan diterapkan oleh produsen terhadap konsumen dapat sesuai dan berjalan dengan baik. Pengelompokkan perilaku-perilaku konsumen ini sering disebut dengan segmentasi.Namun demikian, berdasarkan hasil observasi dan wawancara awal yang penulis lakukan dengan kordinator area pada Alfamart Batukaras diketahui bahwa faktor budaya konsumen belum sepenuhnya mengarah kepada rasionalitas konsumsi, hal tersebut dapat dilihat dari budaya konsumsi masyarakat semakin meningkat dikarenakan adanya pengaruh lingkungan yang menyebabkan konsumen terbiasa untuk mengkonsumsi produk yang dipasarkan oleh perusahaan ritel, ditinjau dari tingkat keseringan konsumen dalam memenuhi kebutuhan pangan. Perubahan gaya hidup konsumen pada era modern terutama yang memilki jumlah penghasilan tinggi menginginkan produk yang praktis guna memenuhi kebutuhan mereka.

Berdasarkan latar belakang tersebut di atas, maka tujuan penelitian ini adalah untuk mengetahui pengaruh faktor pribadi dan budaya terhadap keputusan pembelian.

\section{KAJIAN PUSTAKA}

Manajemen adalah ilmu dan seni mengatur proses pemanfatan sumber daya manusia dan sumber-sumber lainnya secara efektif dan efisien untuk mencapai suatu tujuan tertentu. Manajemen adalah seni dan ilmu 
perencanaan, pengorganisasian, penyusunan, pengarahan dan pengawasan dari pada sumber daya manusia untuk mencapai tujuan yang sudah ditetapkan terlebih dahulu [5].

Informasi yang disajikan pada pelaporan keuangan merupakan tanggung jawab manajemen. Manajemen menyajikan informasi sesuai dengan keadaan yang ada. Namun, pada beberapa entitas internasional pelaporan keuangan tidak hanya dibuat oleh manajemen. Peran fungsi audit internal menjadi lebih diperluas untuk meningkatkan kualitas pelaporan keuangan yang awalnya hanya tanggung jawab manajemen [6].

Manajemen sebagai seni dalam menyelesaikan pekerjaan melalui orang lain. Manajemen merupakan proses perencanaan, pengorganisasian, pengarahan, dan pengawasan usaha-usaha para anggota organisasi dan penggunaan sumber daya-sumber daya manusia organisasi lainnya agar mencapai tujuan organisasi yang telah ditetapkan [7].

Faktor pribadi adalah merupakan suatu cara mengumpulkan dan mengelompokkan kekonsistenan reaksi seorang individu terhadap situasi yang sedang terjadi [8]. Faktor pribadi adalah merupakan pola kebiasaan seseorang yang dipengaruhi oleh lingkungan terdekat dalam menentukan pilihan, kemudian diekspresikan dalam suatu tindakan [8]. Keputusan seseorang untuk membeli juga dipengaruhi oleh karakteristik pribadi yang unik dari masingmasing individu, seperti jenis kelamin, usia dan tahapan dalam siklus hidup, kepribadian, konsep diri dan gaya hidup, karakteristik individu umumnya stabil selama dalam satu siklus hidup seseorang. Misalnya, kebanyakan orang tidak suka merubah jenis kelamin dan tindakannya merubah kepribadian atau gaya hidup yang membutuhkan orientasi kembali selama satu periode kehidupan. Faktor pribadi adalah sebagai karakteristik psikologis seseorang yang berbeda dengan orang lain yang menyebabkan tanggapan yang relatif konsisten dan bertahan lama terhadap lingkungan [4]. Faktor pribadi adalah orang yang memandang berbagai hal secara berbeda akan berperilaku secara berbeda, orang yang memiliki sikap yang berbeda akan memberikan respon yang berbeda terhadap perintah, orang yang memiliki kepribadian yang berbeda berinteraksi dengan cara yang berbeda dengan atasan, rekan kerja dan bawahan [9].

Faktor pribadi merupakan setiap orang mempunyai pandangan, tujuan, kebutuhan dan kemampuan yang berbeda satu sama lain. perbedaan ini akan terbawa dalam dunia kerja, yang akan menyebabkan kepuasan satu orang dengan yang lain berbeda pula. Faktor pribadi adalah sebagai karakteristik psikologis yang dimiliki oleh individu yang berbeda dengan individu lainnya, yang menyebabkan tanggapan yang relatif konsisten dan bertahan lama terhadap lingkungan yang berguna dalam menganalisis keputusan pembelian konsumen terhadap sebuah produk [10].

Berdasarkan beberapa pendapat di atas, maka dapat disimulkan bahwa faktor pribadi adalah sebagai karakteristik psikologis seseorang yang berbeda dengan orang lain yang menyebabkan tanggapan yang relatif konsisten dan bertahan lama terhadap lingkungan. Budaya adalah suatu kompleks yang meliputi pengetahuan, keyakinan, seni, moral, adatistiadat serta kemampuan dan kebiasaan lain yang dimiliki manusia sebagai bagian masyarakat [11].

Pengertian budaya adalah kumpulan nila-nilai dasar, persepsi, keinginan, dan tingkah laku yang dipelajari oleh seorang anggota masyarakat dari keluarga dan lembaga penting lainnya. Setiap masyarakat mempunyai budaya dan pengaruh budaya pada tingkah laku pembelian bervariasi amat besar, oleh karenanya pemasar selalu mencoba menemukan pergeseran budaya agar dapat mengetahui produk baru yang mungkin diinginkan [4]. Budaya (culture) adalah dasar keingan dan perilaku seseorang, pemasar harus benar-benar memperhatikan nilai-nilai budaya jadi setiap negara untuk memahami cara memasarkan kualitas produk, berbagai macam menu makanan yang ditawarkan [12].

Berdasarkan beberapa pendapat di atas, maka dapat disimpulkan bahwa budaya adalah kumpulan nila-nilai dasar, persepsi, keinginan, dan tingkah laku yang dipelajari oleh seorang anggota masyarakat dari keluarga dan lembaga penting lainnya. Pengambilan keputusan adalah proses memilih prosedur tertentu dari berbagai kemungkinan alternative [13].

Keputusan adalah sebuah proses pendekatan penyelesaian masalah yang terdiri dari pengenalan masalah, mencari informasi, beberapa penilaian alternatif, membuat keputusan membeli dan perilaku setelah membeli yang dilalui konsumen [14]. Pengambilan keputusan adalah mengidentifikasikan semua pilihan yang mungkin untuk memecahkan persoalan itu dan menilai pilihan-pilihan secara sistematis dan obyektif serta sasaran-sasarannya yang menentukan keuntungan serta kerugiannya masingmasing [14].

Keputusan pembelian adalah suatu reaksi seseorang terhadap beberapa solusi alternatif yang dilakukan secara sadar dengan cara menganalisa kemungkinan-kemungkinan dari alternatif tersebut 
bersama konsekuensinya [15]. Keputusan pembelian adalah proses pengintegrasian yang mengkombinasi sikap pengetahuan untuk mengevaluasi dua atau lebih perilaku alternatif, dan memilih salah satu diantaranya [16].

Berdasarkan pendapat diatas maka dapat disimpulkan bahwa keputusan pembelian adalah suatu keputusan seseorang dimana dia memilih salah satu dari beberapa alternatif pilihan yang ada dan proses integrasi yang mengkombinasi sikap pengetahuan untuk mengevaluasi dua atau lebih perilaku alternatif dan memilih salah satu diantaranya.

\section{METODE PENELITIAN}

Metode penelitian adalah cara ilmiah untuk mendapatkan data dengan tujuan dan kegunaan tertentu [17]. Sesuai dengan tujuan penelitian yang ingin dicapai dalam penelitian ini, metode penelitian yang digunakan adalah metode penelitian survey explanatory dengan pendekatan data kuantitatif.

Metode survei explanatory adalah merupakan metode penelitian yang dilakukan pada populasi besar maupun kecil, tetapi data yang dipelajari adalah data yang diambil dari sampel dari populasi tersebut, sehingga ditemukan deskripsi dan hubunganhubungan antar variable.

Dalam penelitian ini berupaya mendeskripsikan dan menginterpretasikan hubungan antara variabel dan pengaruhnya berdasarkan data dan informasi yang mendukung sesuai dengan sifat, permasalahan dan tujuan dilakukannya penelitian. Dari data informasi yang dikumpulkan penulis melakukan berbagai analisa untuk mencapai kesimpulan. Data yang diperoleh kemudian diolah, dianalisis dan diproses lebih lanjut dengan dasar-dasar teori yang telah dipelajari untuk menarik kesimpulan. Sedangkan analisis dilakukan melalui pendekatan kuantitatif yang menggunakan metode statistik yang relevan untuk menguji hipotesis.

Adapun populasi dalam penelitian ini jumlah konsumen Alfamart Batukaras secara keseluruhan adalah sebanyak 1.698 orang dengan tingkat eror (kesalahan) yang ditolerir adalah sebesar $10 \%$, hasil perhitungan 94,45 dibulatkan menjadi 94 orang. Jadi ukuran sampel yang dipilih adalah sebanyak 94 orang.

\section{HASIL DAN PEMBAHASAN \\ Pengaruh Faktor Pribadi terhadap Keputusan Pembelian Konsumen pada Alfamart Batukaras}

Analisis ini dimaksudkan untuk mengetahui adanya pengaruh faktor pribadi terhadap keputusan pembelian konsumen pada Alfamart Batukaras.
Analisis ini dugunakan untuk memprediksikan berubahnya bobot variabel tertentu apabila variabel lain berubah. Untuk mengetahui adanya pengaruh faktor pribadi terhadap keputusan pembelian konsumen maka penulis menggunakan rumus koefisien regresi.

Untuk megetahui tingkat hubungan antara variabel faktor pribadi dengan variabel keputusan pembelian konsumen dapat digunakan analisis korelasi sederhana. Berdasarkan hasil perhitungan korelasi product moment tersebut maka diperoleh tingkat hubungan sebesar 0,640. Nilai tersebut berada pada kategori kuat artinya faktor pribadi memiliki hubungan yang kuat dengan keputusan pembelian konsumen pada Alfamart Batukaras [17]. Nilai $r$ juga positif, artinya apabila faktor pribadi meningkat maka keputusan pembelian konsumen akan meningkat.

Untuk mengetahui besarnya presentase pengaruh antara variabel terikat, serta untuk mengetahui pengaruh dari faktor lain di luar variabel bebas. Berdasarkan perhitungan di atas maka dapat di tarik kesimpulan bahwa pengaruh faktor pribadi terhadap keputusan pembelian konsumen pada Alfamart Batukaras sebesar $40,96 \%$ sedangkan $59,04 \%$ dipengaruhi faktor lain yang tidak diteliti.

Untuk menentukan signifikansi maka digunakan nilai thitung. Berdasarkan hasil perhitungan diperoleh nilai thitung sebesar 7.989, selanjutnya adalah membandingkan $\mathrm{t}_{\text {hitung }}$ dan $\mathrm{t}_{\text {tabel }}$. Berdasarkan tabel $\mathrm{t}$ untuk $n=94, d k=n-2$ sehingga $\mathrm{dk}=92$ tidak ada dalam tabel, maka dengan taraf kesalahan sebesar 5\% untuk mengetahui nilai $\mathrm{t}$ tabelnya dalam tabel $\mathrm{t}$ yaitu untuk $\mathrm{n}=60 \mathrm{t}_{\text {tabel }}$ adalah 2,000 dan untuk $\mathrm{n}=120 \mathrm{t}_{\text {tabel }}$ adalah 1,980 .

Korelasi dapat dikatakan signifikan apabila $t_{\text {hitung }}$ $>\mathrm{t}_{\text {tabel }}$ hasil perhitungan di atas dengan $\alpha$ (alpa) untuk uji dua pihak dan $\mathrm{dk}=\mathrm{n}-2$ (92) diperoleh bobot $\mathrm{t}_{\text {hitung }}$ $=7,989$ sedangkan bobot $t_{\text {tabel }}=1,998$, maka $t_{\text {hitung }}>$ $\mathrm{t}_{\text {tabel. }}$ Jadi dari hasil perhitungan ternyata faktor pribadi berpengaruh positif dan signifikan terhadap keputusan pembelian konsumen pada Alfamart Batukaras. Artinya hipotesis yang penulis ajukan yaitu terdapat pengaruh positif faktor pribadi terhadap keputusan pembelian konsumen dapat diterima/teruji kebenarannya.

\section{Pengaruh Faktor Budaya terhadap Keputusan Pembelian Konsumen pada Alfamart Batukaras}

Analisis ini dimaksudkan untuk mengetahui adanya faktor budaya terhadap keputusan pembelian konsumen pada Alfamart Batukaras. Analisis ini 
dugunakan untuk memprediksikan berubahnya bobot variabel tertentu apabila variabel lain berubah. Untuk mengetahui adanya pengaruh faktor budaya terhadap keputusan pembelian konsumen, maka penulis menggunakan rumus koefisien korelasi.

Untuk megetahui tingkat hubungan antara faktor budaya dengan variabel keputusan pembelian konsumen dapat digunakan analisis korelasi sederhana. Berdasarkan hasil perhitungan korelasi product moment tersebut maka diperoleh tingkat hubungan sebesar 0,525. Nilai tersebut berada pada kategori sedang artinya faktor budaya memiliki hubungan yang sedang dengan keputusan pembelian konsumen pada Alfamart Batukaras [17]. Nilai r juga positif, artinya apabila faktor budaya meningkat maka keputusan pembelian konsumen akan meningkat.

Untuk mengetahui besarnya presentase pengaruh antara variabel terikat, serta untuk mengetahui pengaruh dari faktor lain di luar variabel bebas. Berdasarkan perhitungan di atas maka dapat di tarik kesimpulan bahwa pengaruh faktor budaya terhadap keputusan pembelian konsumen pada Alfamart Batukaras sebesar 27,56\%. Sedangkan 72,44\% dipengaruhi faktor lain yang tidak diteliti.

Untuk mengetahui signifikasi maka digunakan nilai $t_{\text {hitung. }}$. Berdasarkan hasil perhitungan diperoleh nilai thitung sebesar 5,917 selanjutnya adalah membandingkan $\mathrm{t}$ hitung dan $\mathrm{t}$ tabel. Berdasarkan tabel $\mathrm{t}$ untuk $\mathrm{n}=94, \mathrm{dk}=\mathrm{n}-2$ sehingga $\mathrm{dk}=92$ tidak ada dalam tabel, maka dengan taraf kesalahan sebesar 5\% untuk mengetahui nilai $t$ tabelnya dalam tabel $t$ yaitu untuk $n$ $=60 \mathrm{t}_{\text {tabel }}$ adalah 2,000 dan untuk $\mathrm{n}=120 \mathrm{t}_{\text {tabel }}$ adalah 1,980 menggunakan rumus interpolasi.

Korelasi dapat dikatakan signifikan apabila $t_{\text {hitung }}$ $>\mathrm{t}_{\text {tabel }}$ hasil perhitungan di atas dengan $\alpha$ (alpa) untuk uji dua pihak dan $\mathrm{dk}=\mathrm{n}-2$ (92) diperoleh bobot $\mathrm{t}$ hitung $=5,917$ sedangkan bobot $\mathrm{t}_{\text {tabel }}=1,998$, maka $\mathrm{t}_{\text {hitung }}>\mathrm{t}$ tabel. Jadi dari hasil perhitungan ternyata faktor budaya berpengaruh positif dan signifikan terhadap keputusan pembelian konsumen pada Alfamart Batukaras. Artinya hipotesis yang penulis ajukan yaitu terdapat pengaruh positif faktor budaya terhadap keputusan pembelian dapat diterima/teruji kebenarannya.

\section{Pengaruh Faktor Pribadi dan Faktor Budaya terhadap Keputusan Pembelian Konsumen pada Alfamart Batukaras}

Untuk mengetahui pengaruh faktor pribadi dan faktor budaya terhadap keputusan pembelian konsumen pada Alfamart Batukaras maka penulis menggunakan rumus koefisien regresi berganda. Untuk mengetahui pengaruh faktor pribadi dan faktor budaya terhadap keputusan pembelian konsumen pada Alfamart Batukaras maka penulis menggunakan rumus koefisien regresi berganda.

Analisis ini digunakan untuk mengetahui pengaruh variabel $\mathrm{X}_{1}$ (faktor pribadi) dan variabel $\mathrm{X}_{2}$ (faktor budaya) terhadap variabel $\mathrm{Y}$ (keputusan pembelian) secara bersamaan. Dari perhitungan analisis regresi dapat diketahui persamaan regresinya yaitu $\mathrm{Y}=\mathrm{a}+\mathrm{bX} 1+\mathrm{bX} 2$ atau $\mathrm{Y}=15,138+0,463 \mathrm{X}_{1}+$ $0,160 \mathrm{X}_{2}$ apabila nilai $\mathrm{X}_{1}$ bertambah 1 maka nilai $\mathrm{Y}$ akan mengalami kenaikan sebesar 0,463 , begitu pula dengan peningkatan $\mathrm{X}_{2}$ bertambah 1 maka nilai $\mathrm{Y}$ akan mengalami kenaikan sebesar 0,160. Jika $X_{1}$ dan $X_{2}$ tidak bertambah atau sama dengan nol maka nilai $\mathrm{Y}$ sebesar 15,138 .

Selanjutnya untuk mengetahui hubungan variabel faktor pribadi dan faktor budaya dengan keputusan pembelian konsumen pada Alfamart Batukaras digunakan analisis koefisien korelasi ganda. Dalam penelitian ini yang menjadi variabel bebas adalah faktor pribadi (X1) dan faktor budaya (X2) sedangkan variabel terikatnya ialah keputusan pembelian (Y). Diketahui nilai $r_{x 1 y}$ dan $r_{x 2 y}$ adalah berturut-turut 0,640 dan 0,525. Sedangkan untuk nilair $r_{x 1 \times 2}$ belum diketahui, sehingga sebelum mensubtitusikan nilai $r$ ke dalam rumus korelasi ganda di atas, maka terlebih dahulu mencari $\mathrm{r}_{\mathrm{x} 1 \times 2}$. Dari hasil análisis tersebut diperoleh hasil $r$ sebesar 0,694. Berdasarkan penafsiran tingkat pengaruh $r=0,694$ termasuk kategori kuat dan mempunyai arah yang positif [17]. Dengan demikian tingkat korelasi (hubungan) antara faktor pribadi dan faktor budaya dinyatakan memiliki hubungan yang kuat.

Dan selanjutnya didistribusikan kedalam rumus korelasi ganda. Dari hasil analisis tersebut diperoleh hasil $\mathrm{R}$ sebesar 0,845 . Berdasarkan penafsiran tingkat pengaruh $r=0,845$ termasuk kategori sangat kuat dan mempunyai arah yang positif [17]. Dengan demikian tingkat korelasi (hubungan) dua variabel bebas antara faktor pribadi $\left(\mathrm{X}_{1}\right)$ dan faktor budaya $\left(\mathrm{X}_{2}\right)$ secara simultan (bersama-sama) dengan variabel terikat keputusan pembelian konsumen (Y) dinyatakan memiliki hubungan yang sangat kuat. Nilai $R$ juga positif, artinya jika faktor pribadi dan faktor budaya meningkat maka keputusan pembelian konsumen akan meningkat.

Untuk mengetahui besarnya prosentase pengaruh antara variabel terikat, serta untuk setuju pengaruh dari faktor lain diluar variabel bebas. Berdasarkan perhitungan di atas maka dapat di tarik kesimpulan bahwa pengaruh faktor pribadi dan faktor budaya terhadap keputusan pembelian konsumen pada 
Alfamart Batukaras sebesar $71,40 \%$ sedangkan 28,60\% dipengaruhi faktor lain yang tidak diteliti.

Uji F pada dasarnya menunjukkan apakah semua variabel bebas yang dimasukkan dalam model mempunyai pengaruh secara bersama-sama terhadap variabel terikat. Dalam penelitian ini pengujian hipotesis secara simultan dimaksudkan untuk mengukur besarnya pengaruh faktor pribadi dan faktor budaya terhadap keputusan pembelian konsumen. Dari hasil perhitungan, diketahui bahwa $F_{\text {hitung }}$ sebesar 134,81 lebih besar dari $F_{\text {tabel }}$ sebesar 3,094, itu artinya hipotesis diterima, dengan demikian maka secara bersama-sama (simultan) faktor pribadi dan faktor budaya berpengaruh positif dan signifikan terhadap keputusan pembelian konsumen pada Alfamart Batukaras. Dengan demikian bahwa hipotesis yang diajukan yaitu terdapat pengaruh positif faktor pribadi dan faktor budaya terhadap keputusan pembelian konsumen dapat diterima/teruji kebenarannya.

\section{KESIMPULAN DAN SARAN}

Berdasarkan hasil penelitian dan pembahasan maka dapat disimpulkan sebagai berikut: 1) Terdapat pengaruh yang positif dan signifikan faktor pribadi terhadap keputusan pembelian konsumen pada Alfamart Batukaras. Artinya jika faktor pribadi meningkat maka keputusan pembelian konsumen akan meningkat; 2) Terdapat pengaruh yang positif dan signifikan faktor budaya terhadap keputusan pembelian konsumen pada Alfamart Batukaras. Artinya jika faktor budaya meningkat maka keputusan pembelian konsumen akan meningkat, 3) Terdapat pengaruh yang positif dan signifikan faktor pribadi dan faktor budaya terhadap keputusan pembelian konsumen pada Alfamart Batukaras. Artinya jika faktor pribadi dan faktor budaya meningkat maka keputusan pembelian konsumen akan meningkat.

\section{REFERENSI}

[1] Antonacopoulou, E. P. (2007). Actionable knowledge. In S. Clegg, \& J. Bailey (Eds.), International encyclopedia of organization studies (pp. 14-17). London: SAGE.

[2] Argote, L. (2011). Organizational learning research: Past, present, and future. ManagementLearning, 42(4), 439-446.

[3] Argote, L. (2012). Organizational learning: Creating, retaining and transferring knowledge.Springer Science \& Business Media.
[4] Argyris, C., \& Schön, D. A. (1978). Organizational learning: A theory of action perspective, Vol. 173. Reading, MA: AddisonWesley.

[5] Argyris, C. (2009). On organizational learning (2nd ed.). USA: Blackwell Publishing.

[6] Baron, R. A. (2006). Opportunity recognition as pattern recognition: How entrepreneurs connect the dots to identify new business opportunities. The Academy of Management Perspectives, 20(1), 104-119.

[7] Biggs, J., \& Tang, C. (2009). Teaching for quality learning at university society for research into higher education (5th ed.). England: McGraw Hill.

[8] Brady, T., \& Davies, A. (2004). Building project capabilities: From exploratory to exploitative learning. Organization Studies, 25(9), 16011621.

[9] Colquitt, J. A., \& Zapata-Phelan, C. P. (2007). Trends in theory building and theory testing: A five-decade study of the Academy of Management Journal. Academy of Management Journal, 50(6), 1281-1303.

[10] Corley, K. G., \& Gioia, D. A. (2011). Building theory about theory building: What constitutes theoretical contribution? Academy of Management Review, 36(1), 12-32.

[11] Crossan, M. M., \& Apaydin, M. (2010). A multidimensional framework of organizational innovation: A systematic

[12] BakerH Kent, E Theodore, G. E. P. (2009). Dividend Policy, Creditor Rights, and the Agency Costs of Debt. Journal of Financial Economics, 38, 276-299.

[13] review of the literature. Journal of Management Studies, 47(6), 1154-1191.

[14] Condie, J. (2012). Qualitative Research in Accounting \& Management Article information: Qualitative Research in Accounting \& Management, 9(2), 168-193.

[15] Baxter, J., Chua, W. F., Elharidy, A. M., Nicholson, B., Scapens, R. W., \& Gurd, B. (2008). Qualitative Research in Accounting \& Management"Remaining consistent with method? An analysis of grounded theory research in accounting. Qualitative Research in Accounting \& Management Qualitative Research in Accounting \& Management Qualitative Research in Accounting \& Management, 5(7), 101-121. https://doi.org/10.1108/11766090810888917 